\title{
IMPLEMENTASI PEMBELAJARAN TEMATIK DI SD N KEMASAN 1 POLOKARTO
}

\author{
Meidawati Suswandari \\ Universitas Veteran Bangun Nusantara \\ Email: moetis meida@yahoo.co.id
}

\begin{abstract}
Abstrak
Penelitian ini bertujuan untuk mendeskripsikan implementasi pembelajaran tematik di SD N Kemasan 1, Polokarto. Penelitian ini menggunakan pendekatan deskriptifkualitatif. Teknik pengambilan sampel menggunakan purposive sampling. Informan dalam penelitian ini adalah guru dan siswa kelas V SD N Kemasan 1 Polokarto. Teknik pengumpulan data yang digunakan meliputi observasi dan dokumentasi. Analisis data menggunakan teknik reduksi data, penyajian data, dan penarikan kesimpulan. Hasil penelitian menunjukkan bahwa proses pembelajaran tematik di SD N Kemasan 1 Polokarto meliputi1) berpusat pada peserta didik. 2) memberikan pengalaman langsung pada peserta didik (direct experiences) 3) pemisahan antara mata pelajaran tidak begitu nyata dan jelas. 4) menyajikan suatu konsep dari berbagai mata pelajaran dalam suatu proses pembelajaran 5) fleksibel atau luwes. 6) hasil pembelajaran sesuai dengan minat dan kebutuhan siswa sebab siswa diberikan kesempatan untuk mengoptimalkan potensinya sesuai dengan keinginannya.
\end{abstract}

Kata Kunci: pembelajaran tematik, siswa, guru, sekolah dasar

\begin{abstract}
This study aims to describe the implementation of thematic learning in $S D N$ Kemasan 1, Polokarto. This research use desciptive qualitative approach. The sampling technique used purposive sampling. The informants in this study were teachers and fifth grade students of SD N Kemasan 1 Polokarto. Data collection techniques used include observation and documentation. Data analysis using data reduction techniques, data presentation, and drawing conclusions. The results showed that the thematic learning process at SD N Kemasan 1 Polokarto includes 1) learner-centered. 2) provide direct experiences to students (direct experiences) 3) the separation between subjects is not so real and clear. 4) presents a concept from various subjects in a learning process 5) flexible or flexible. 6) learning outcomes are in accordance with students' interests and needs because students are given the opportunity to optimize their potential according to their wishes.
\end{abstract}

Keywords: thematic learning, students, teachers, elementary schools

\section{Pendahuluan}

Membangun pembelajaran yang efektif adalah menciptakan pembelajaran aktif yang memberdayakan siswa untuk mencapai kompetensinya. Pembelajaran aktif merupakan pembelajaran yang bersifat student centered yang menekankan siswa tidak pasif dalam proses belajar mengajar. Sementara itu, proses pembelajaran yang pasif menciptakan suasana belajar yang tidak ada kerjasama antar siswa, siswa tidak

33 | Implementasi Pembelajaran Tematik di SDN Kemasan 1 Polokarto 


\section{Meidawati Suswandari}

percaya diri, dan siswa sulit menciptakan antusias siswa, tidak berkomunikasi sesama teman ataupun disertai suasana tegang dan guru. Proses pembelajaran yang membangkitkan motivasi belajar siswa. berlangsung tersebut, cenderung Iklim pembelajaran tersebut dapat berpusat pada guru/teacher centered menghilangkan rasa canggung siswa (Fayombo, 2015: 83; Misseyanni, Lytras, ketika pembelajaran di kelas, baik antara Papadopoulou, \& Marouli, 2018: 399- siswa dan guru, maupun antar siswa. 400). Guru berfokus pada penyampaian Iklim pembelajaran berbentuk interaksi materi (pengetahuan) saja dan kurang sosial antara guru dan siswa dalam memperhatikan penilaian dalam aspek berbicara, mengemukakan pendapat, afektif serta psikomotorik siswa. dan mengajukan pertanyaan pada guru Pembelajaran efektif ditujukan dengan (Akin, 2018: 19-20; Elliot, 2015: 3).

kemampuan siswa dalam belajar dengan Jika situasi pembelajaran yang caranya sendiri. Dengan demikian, terbangun maksimal dalam interaksi proses pembelajaran efektif dilakukan sosial antara guru dengan siswa maka dengan keterlibatan keaktifan siswa dan berdampak secara maksimal pada guru tidak mengambil hak siswa untuk keberlangsungan pembelajaran tematik memperoleh kesempatan membangun di kelas. Pembelajaran tematik sendiri pengetahuannya sehingga merupakan pendekatan pembelajaran memperoleh pemahaman secara yang mengintegrasikan berbagai mendalam (Afandi, Evi, \& Oktarina, kompetensi dari berbagai mata pelajaran 2013: 24-25; Irwan \& Nasution, 2016: 11- ke dalam berbagai tema. 12).

Pengintegrasian terwujud dalam dua hal,

Suasana belajar yang kondusif yakni: (1) integrasi sikap, keterampilan, adalah suasana belajar dengan dan pengetahuan dalam proses kenyamanan dan ketenangan. Nyaman pembelajaran; dan (2) integrasi berbagai artinya suasana belajar terhindar dari konsep dasar yang terkait. Tema suara dan bunyi yang merusak dikemas dalam berbagai konsep kosentrasi belajar siswa seperti sehingga siswa tidak belajar konsep keramaian di sekitar lingkungan pengetahuan/pemahaman secara kelas/sekolah. Menyenangkan artinya terpisah. Oleh sebab itu, pembelajaran suasana belajar siswa gembira, 34 | Autentik: Jurnal Pengembangan Pendidikan Dasar, Vol.5, No.1, Februari 2021 
ISSN 2548-9119

dapat bermakna dan berjalan utuh (Arifin, 2016).

Karakteristik

pembelajaran

tematik yang menjadi pembeda dengan pembelajaran yang lain adalah sebagaimana berikut: (1) Berpusat pada peserta didik. Pembelajaran dengan menempatkan siswa sebagai subjek belajar, sedangkan guru sebagai fasilitator, (2) Memberikan pengalaman langsung pada peserta didik (direct experiences); sehingga siswa belajar secara nyata, (3) Pemisahan antara mata pelajaran tidak begitu nyata dan jelas yaitu fokus pembelajaran pada pembahasan tema-tema yang terdekat dengan kehidupan siswa, (4) Menyajikan konsep dari berbagai mata pelajaran dalam suatu proses pembelajaran agar secara utuh dan membantu permasalahan siswa dalam kehidupan sehari-hari, (5) Fleksibel atau luwes, artinya bahan ajar dalam satu mata pelajaran dapat dikaitkan dengan mata pelajaran yang lainnya, (6) Hasil pembelajaran sesuai dengan minat dan kebutuhan siswa agar mengoptimalkan potensi siswa, (7) Adanya prinsip belajar sambil bermain, sehingga proses pembelajaran bermakna dan menyenangkan (Purwanti, Septiningrum, Hidayat, \& Hidayah, 2018).
Khususnya pembelajaran tematik di Sekolah Dasar. Hal ini tertuang dalam Permendikbud Nomor 65 Tahun 2013 Tentang Standar Proses Pendidikan Dasar dan Menegah yang menyebutkan bahwa "Sesuai dengan Standar Kompetensi Lulusan dan Standar Isi, maka prinsip pembelajaran yang digunakan dari pembelajaran parsial menuju pembelajaran terpadu". Pelaksanaan kurikulum 2013 pada SD/MI dilakukan melalui pendekatan tematik terpadu/integratif dari kelas I sampai kelas VI Kemendikbud (2013: 189)., Wahyuni, Setyosari \& Kuswandi (2016: 132-133).

Pembelajaran tematik yang harus ada keterapaduan dan sinergitas tersebut, juga dilakukan di SD $\mathrm{N}$ Kemasan 1 Polokarto. Pada saat observasi bulan November 2019 di SD N Kemasan 1, Polokarto, proses pembelajaran tematik telah berpusat pada siswa yang ditunjukan ketika pengamatan di kelas V SD N Kemasan 1. Proses pembelajaran dalam bentuk siswa belajar mengamati objek sesuai dengan tema/materi, mencoba untuk melakukan percobaan dan mengikuti instruksi guru dan mengkomunikasikan di depan kelas. Hasil observasi dikelas $\mathrm{V}$ SD $N$ Kemasan 1 pada saat proses 35 | Implementasi Pembelajaran Tematik di SDN Kemasan 1 Polokarto 
pembelajaran tematik tentang jual beli dengan menggunakan metode bermain peran. Ada yang berperan sebagai penjual dan pembeli. Peran tersebut memunculkan interaksi antara penjual dan pembeli. Keduanya saling berkomunikasi untuk mendapatkan kesepakatan jual beli barang. Dengan pembelajaran seperti in, maka siswa dapat belajar bagaimana cara berkomunikasi yang baik (mata pelajaran Bahasa Indonesia), materi tentang pasar tersebut (penjual, pembeli, tawarmenawar) merupakan bagian dari mata pelajaran IPS. Sedangkan tawar menawar harga yang terjadi antara penjual dan pembeli merupakan bagian dari mata pelajaran matematika, sehingga proses pembelajaran mejadi bermakna dengan mengkaitkan antar konsep mata pelajaran satu dengan mata pelajaran lain.

Akan tetapi pada satu sisi, berdasarkan hasil wawancara dengan guru dan beberapa siswa, terlihat siswa lebih senang dengan pembelajaran tematik daripada pembelajaran KTSP karena beban belajar yang ringan. Tetapi dalam pelaksanaan di kelas memang ada beberapa siswa yang masih bingung dengan pembelajaran tematik.
Pembelajaran tematik yang menarik bagi siswa dengan konsep belajar sambil bermain, peneliti lakukan penelitian lebih mendalam dalam bentuk deskripsi. Oleh sebab itu, tujuan penelitian ini adalah untuk mendeskripsikan implementasi pembelajaran tematik di SD N Kemasan 1, Polokarto.

\section{Metode Penelitian}

Penelitian ini menggunakan pendekatan deskriptif-kualitatif. Pendekatan kualitatif digunakan dalam penelitian ini untuk mendeskripsikan implementasi pembelajaran tematik di SD N Kemasan 1, Polokarto. Selain itu pendekatan kualitatif deskriptif lebih efektif digunakan dalam penelitian ini karena dapat menggali data penelitian secara mendalam. Informan dipilih dengan menggunakan purposive sampling. Sedangkan informan dalam penelitian ini adalah guru dan siswa di SD N Kemasan 1 Polokarto.

Teknik pengumpulan data yang digunakan peneliti adalah observasi dan dokumentasi. Observasi merupakan kegiatan observasi untuk mendapatkan kedalaman data melalui fenomena yang muncul selama penelitian khususnya mengenai proses pembelajaran tematik 
pada kurikulum 2013 di kelas V SD N yang dikumpulkan melalui observasi dan Kemasan 1 Polokarto. Dokumentasi dokumentasi kemudian diolah dengan adalah pencarian data melalui arsip, menggunakan analisis data interaktif. dokumen, foto dan file / portofolio yang Adapun analisis interaktif meliputi digunakan oleh guru dalam proses tahapan reduksi data, penyajian data, pembelajaran tematik pada kurikulum dan penarikan kesimpulan.

2013. Selanjutnya dari keseluruhan data

\author{
Bagan 1. Analisis Interaktif Milles \& Huberman
}

OVERVIEW OF QUALITATIVE DATA ANALYSIS

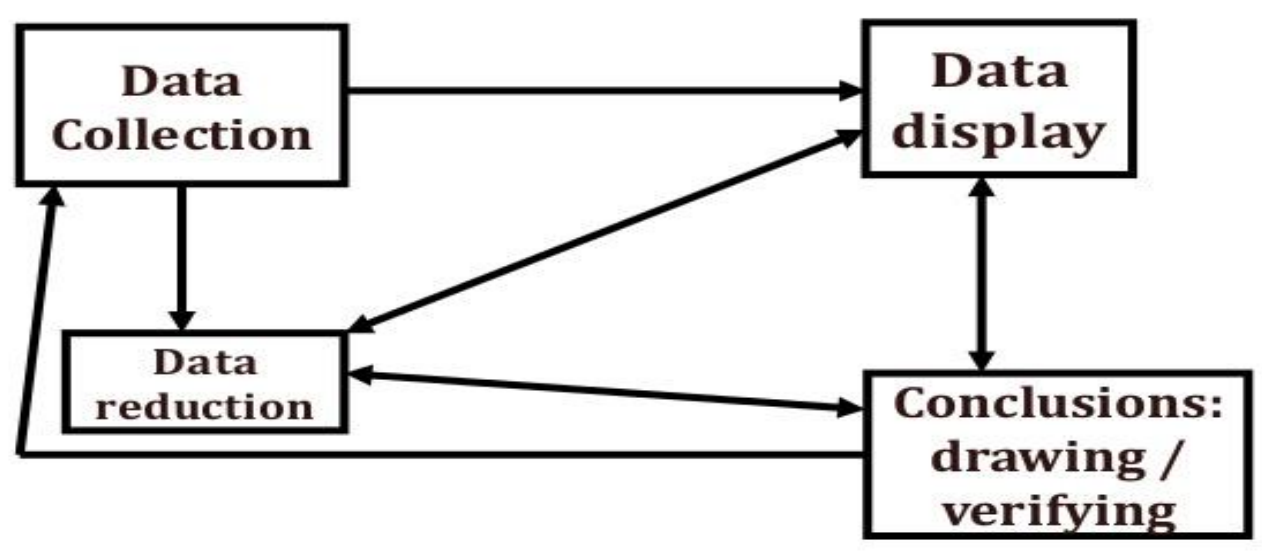

(Miles \& Huberman, 1994)

\section{Hasil dan Pembahasan}

Hasil penelitian Sekolah Dasar Negeri Kemasan 1 Polokarto terkait tujuan penelitian tentang pelaksanaan proses pembelajaran tematik terbagi dalam 7 karakteristik pembelajaran tematik, antara lain:

1. Pembelajaran bersifat student active learning atau pembelajaran yang
Berpusat pada siswa. Artinya, pembelajaran menempatkan siswa sebagai subjek belajar, sedangkan posisi guru sebagai fasilitator.

Pembelajaran tematik yang menitikberatkan keterlibatan siswa sebagai sumber belajar sehingga siswa dapat memperoleh pengalaman belajar secara langsung. Hal ini bertujuan dapat 
menemukan sendiri berbagai pengetahuan yang dipelajarinya. Siswa yang aktif akan mampu memahami materi dengan kegiatan terlibat langsung, seperti demonstrasi dan diskusi. Namun bagi siswa yang pasif, tidak dapat mengikuti materi yang sedang dipelajarinya. Pelaksanaan pembelajaran tematik di SD N Kemasan 1 berpusat pada siswa sehingga membutuhkan kesiapan dari siswa dan guru. Guru dapat mengkondisikan pembelajaran di kelas dengan pembelajaran yang menyenangkan sehingga siswa dapat belajar dengan senang, nyaman dan dapat memahami materi yang disampaikan.

Hal ini sependapat dengan Fayombo, 2015: 83; Misseyanni, Lytras, Papadopoulou, \& Marouli, 2018: 399-400 bahwa pembelajaran aktif merupakan pembelajaran yang bersifat student centered yang menekankan siswa tidak pasif dalam proses belajar mengajar. Dalam hal ini bertujuan untuk membangun pembelajaran yang efektif dan menciptakan pembelajaran aktif yang memberdayakan siswa untuk mencapai kompetensinya. Pembelajaran efektif ditujukan dengan kemampuan siswa dalam belajar dengan caranya sendiri. Dengan demikian, proses pembelajaran efektif dilakukan dengan keterlibatan keaktifan siswa dan guru tidak mengambil hak siswa untuk memperoleh kesempatan membangun sendiri pengetahuannya sehingga memperoleh pemahaman secara mendalam (Afandi et al., 2013; M Suswandari, 2017; Wahyuni, H.T, Setyosari, P \& Kuswandi, 2016)

Pada kegitan inti pembelajaran tematik menempatkan guru untuk memberikan contoh dan berperan sebagai fasilitator. Pada kegiatan inti guru selalu mengadakan tanya jawab dengan siswa dan sebisa mungkin mencoba bertindak sebagai fasilitator tujuannya adalah agar dapat membantu siswa untuk lebih mandiri dan aktif terlibat dalam pembelajaran. Guru juga menggunakan media pembelajaran walau sifatnya masih sederhana. Media dalam pembelajaran tematik merupakan hal yang penting dan tidak semata-mata hanya untuk pelengkap pembelajaran saja namun penggunaan media bertujuan untuk mempermudah siswa dalam memahami materi, menyamakan presepsi siswa terhadap materi, mempermudah guru dalam penyampaian materi, dan agar proses pembelajaran dapat berjalan secara efektif (Suswandari, 2019). . Hal ini terlihat 38 | Autentik: Jurnal Pengembangan Pendidikan Dasar, Vol.5, No.1, Februari 2021 
pada guru kelas $\mathrm{V}$ di SD $\mathrm{N}$ Kemasan 1 ketika proses pembelajaran tematik dengan memberikan contoh dan mengaitkan materi berdasarkan kehidupan nyata siswa.

Pembelajaran tematik pada kurikulum 2013 tersebut juga identik dengan pendekatan ilmiah. Pendekatan ilmiah ini diistilahkan pendekataan saintifik. Implementasi pendekatan saintifik dalam pembelajaran tematik ini meliputi 5 tahapan, yaitu Mengamati, Menanya, Mencoba, Mengasosiasi, dan Mengkomunikasi. Hal ini sependapat dari hasil wawancara dengan Kepala Sekolah SD N Kemasan 1.

"Bagus kurikulum 2013 dengan istilah pendekatan scientific yang mana siswa diarahkan pada $5 \mathrm{M}$ yaitu mengamati, menanya, menalar, mencoba, dan membuat jejaring". (wawancara kepala sekolah SD N Kemasan 1 Polokarto).

2. Memberikan pengalaman langsung pada peserta didik (direct experiences) secara nyata sebagai dasar untuk memahami hal-hal bersifat abstrak.

Pembelajaran tematik memberikan penekanan dengan belajar sambil melakukan sesuatu (learning by doing). Sehingga peran guru perlu menciptakan pembelajaran yang merancang siswa belajar secara langsung. Salahsatunya merancang dalam pembuatan RPP tematik. Rancangan RPP tematik oleh guru perlu dirancang dan dikemas sesuai pengalaman belajar yang bermakna bagi siswa. Siswa akan mendapatkan pengalaman belajar yang berkaitan dengan kehidupan nyata (konseptual). Integrasi antar mata pelajaran dapat membuat siswa belajar secara utuh. Selain itu, penerapan pembelajaran tematik di sekolah dasar sangat membantu siswa, karena sesuai dengan tahap perkembangan siswa.

Pembelajaran tematik lebih menekankan pada penerapan konsep belajar sambil melakukan sesuatu (learning by doing). Pembuatan RPP oleh guru perlu dirancang dan dikemas sesuai pengalaman belajar yang bermakna bagi siswa. Pengalaman belajar yang berkaitan dengan kehidupan nyata (konseptual) menjadikan proses pembelajaran lebih efektif. Kaitan konseptual antar mata pelajaran yang dipelajari akan membentuk skema, sehingga siswa akan memperoleh keutuhan dan kebulatan pengetahuan. Selain itu, penerapan pembelajaran tematik di sekolah dasar sangat membantu siswa, karena sesuai

39 | Implementasi Pembelajaran Tematik di SDN Kemasan 1 Polokarto 


\section{Meidawati Suswandari}

dengan tahap perkembangan siswa yang masih melihat segala sesuatu sebagai satu keutuhan. Pernyataan tersebut sependapat dengan teori belajar konstruktivisme bahwa cara guru dalam mengajar yang berpusat pada pembelajaran siswa yang menjelaskan bagaimana seseorang belajar dengan membangun pengetahuan dengan pembelajaran bermakna yang berasal dari pengalaman terdekat siswa (Suhendi, 2018; Suswandari, 2018).

Hasil observasi di kelas V SD N Kemasan 1 terkadang guru mampu menghubungkan materi dengan kehidupan sehari-hari siswa dengan mengambil beberapa contoh pada kehidupan sehari-hari yang dialami oleh sekitar lingkungan siswa. Cara ini dilakukan oleh guru sebagai bagian dari mengaitkan materi yang sesuai dengan kisah atau pengalaman nyata di sekitar siswa. Tujuan saling mengkaitkan dalam proses pembelajaran yaitu siswa akan terbiasa dan siswa tidak melihat mata pelajaran itu berdiri sendiri. Namun siswa melihat objek atau peristiwa itu terdapat sejumlah konsep/materi dari beberapa pelajaran. Berikut hasil wawancara dengan guru kelas $\mathrm{V}$ di SD $\mathrm{N}$ Kemasan 1 menyatakan bahwa :
"Saat dalam menyampaikan materi pembelajaran sebisa mungkin yang disampaikan dengan mengambil contoh-contoh sekitar anak. Hal ini bertujuan untuk memudahkan dan memahami maksud dari materi yang sedang saya sampaikan. Oleh sebab itu, contoh harus konkret".

3. Pemisahan antara mata pelajaran kurang jelas dan nyata dari tematema yang paling dekat dengan kehidupan siswa.

Hal ini pula terjadi pada guru di SD N Kemasan 1 Polokarto kesulitan dalam mengaitkan materi dari satu mata pelajaran dengan mata pelajaran yang lainnya. Pengkaitan mata pelajaran yang menghubungkan keadaan sekitar siswa agar memudahkan dan membelajarkan siswa untuk belajar menyenangkan di kelas. Menyenangkan bisa diwujudkan dalam bentuk bermain tebak kata, menari, menyanyi, dan teka-teki. Menyenangkan tidak dimaksudkan banyak tertawa atau banyak bernyanyi. Menyenangkan artinya 'mengasyikan', dan siswa secara fisik maupun mental terlibat dalam proses pembelajaran sejak perencanaan hingga evaluasi pembelajaran. Selain itu, melalui pengkaitan ini juga siswa juga diharapkan adanya pemberian 
ISSN 2548-9119

kesempatan untuk mengembangkan potensi yang dimiliki sesuai dengan minat dan kebutuhannya.

strategi, mempersiapkan dan menggunakan media serta merencanakan evaluasi atas pembelajaran yang telah dilaksanakan

4. Menyajikan suatu konsep dari berbagai mata pelajaran secara utuh untuk membantu permasalahan siswa dalam kehidupan sehari-hari.

Pembelajaran tematik dalam memadukan konsep mata pelajaran yang satu dengan yang lain, salah satu tujuan pembelajaran tematik yaitu menciptakan suasana pembelajaran yang menyenangkan. Misalnya memadukan konsep mata pelajaran bahasa Indonesia dengan konsep mata pelajaran IPA dari kedua konsep mata pelajaran yang berbeda guru mampu meramunya sehingga membuat satu tema yang kemudian dibuatkan Rencana Pelaksanaan Pembelajaran (RPP) itulah keistimewaan dari Rencana pembelajaran tematik yaitu penggabungan dari beberapa mata pelajaran.

Perencanaan pembelajaran tematik guru harus memperhatikan hal-hal tersebut dengan cara mengkaji silabus terlebih dahulu. Selanjutnya mempersiapkan materi, menentukan tujuan, mempersiapkan metode dan apakah telah tercapai atau harus ada pengulangan dan tindak lanjut.

Mengkaji Silabus menurut lbu Betty, S,Pd (Guru Kelas V Sekolah Dasar Negeri Kemasan 1) merupakan acuan penyusunan kerangka pembelajaran, yang mencakup standar kompetensi kompetensi dasar materi pokok, kegiatan pembelajaran, alokasi waktu sumber belajar, dan penilaian Silabus ini akan sangat bermanfaat sebagai pedoman guru karena menyesuaikan tujuan dan ruang lingkup materi yang harus dipelajari oleh siswa. Selain itu, juga menerangkan tentang kegiatan belajar mengajar, media, dan evaluasi yang harus digunakan dalam proses pembelajaran kepada siswa.

Selanjutnya perangkat setelah silabus diturunkan dalam bentuk RPP. Pada umumnya RPP pada kurikulum 2013 setiap satu tema dilaksanakan selama 3 minggu, sedangkan dalam 1 Minggu ada 6 kali pertemuan. Jadi dalam satu tema dilaksanakan dalam 18 kali pertemuan. Melalui pembelajaran tematik guru mengemas pembelajaran dengan sebuah tema menarik, guru 41 | Implementasi Pembelajaran Tematik di SDN Kemasan 1 Polokarto 


\section{Meidawati Suswandari}

senantiasa menciptakan suasana belajar menjadi arena bermain yang mendidik, membuat materi pembelajaran menjadi lebih nyata. Guru merencanakan pembelajaran secara tertulis maupun tidak tertulis. RPP yang dibuat oleh guru telah termuat identitas sekolah, tema, sub tema, muatan pelajaran, Kompetensi Inti (KI), Kompetensi Dasar (KD) yang diuraikan menjadi indikator.

Hal ini juga atas dasar kebijakan pendidikan nasional yang dituangkan dalam Permendiknas RI No. 52 Tahun 2008 tentang Standar Proses yang berisikan komponen Rencana Pelaksanaan Pembelajaran (RPP) harus memuat tujuan pembelajaran. Permendiknas RI No. 52 Tahun 2008 tentang Standar Proses menyebutkan bahwa tujuan pembelajaran memberikan petunjuk untuk memilih mata pelajaran menata urutan topik-topik, mengalokasikan waktu, petunjuk dalam memilih alat-alat bantu untuk pembelajaran melalui prosedur pengajaran serta ketersediaan alat ukur (evaluasi) yang standar untuk mengukur prestasi belajar siswa (Nugraha, Sudiatmi, \& Suswandari, 2020).

5. Fleksibel atau luwes, artinya bahan ajar dalam satu mata pelajaran dapat dikaitkan dengan mata pelajaran yang lainnya, bahkan dapat dikaitkan dengan lingkungan tempat sekolah dan siswa berada.

Pembelajaran tematik memiliki sifat yang fleksibel/luwes bahwa guru mampu mengaitkan bahan ajar dari satu mata pelajaran dengan mata pelajaran yang lainnya, bahkan mengaitkannya dengan kehidupan siswa dan keadaan lingkungan tempat sekolah dan siswa berada. Sehingga pemahaman materi siswa berdampak pada kebermaknaan, holistik dan bahkan meningkatkan minat. Pembelajaran dengan menggunakan prinsip belajar sambil bermain dan menyenangkan pun menjadi prioritas dalam menerapkan pembelajaran tematik.

Penyajian konsep/materi/bahan ajar dari berbagai muatan mata pelajaran secara fleksibel dengan menggunakan prinsip belajar sambil bermain dan menyenangkan. Melalui pembelajaran tematik dapat bermakna karena adanya pemberiankesempatan kepada siswa untuk mengerjakan tugas-tugas. Hasil observasi di SD $\mathrm{N}$ Kemasan 1, guru belum maksimal dalam memberikan kesempatan kepada siswa untuk mengerjakan tugas- tugas secara

42 | Autentik: Jurnal Pengembangan Pendidikan Dasar, Vol.5, No.1, Februari 2021 
ISSN 2548-9119

berkelompok. Hal ini terlihat dari ciri/karakteristik siswa serta situasi dan beberapa metode, model, pendekatan, kondisi di kelas.

dan media pembelajaran yang digunakan oleh guru di kelas.

6. Hasil pembelajaran diperoleh dari Berdasarkan hasil wawancara minat dan kebutuhan siswa agar guru SD N Kemasan 1 mengungkapkan bahwa:

"Seorang guru atau pendidik yang berprofesional mampu menggunakan metode yang bervariasi dengan luwes, baik dan berkesinambungan seperti diskusi kelompok dan lainnya"

Arti luwes atau fleksibel juga dimaknai dalam bentuk pembuatan perencanaan pembelajaran. Pembuatan RPP yaitu dalam menentukan indikatorindikator yang saling berkaitan antara mata pelajaran satu dengan yang lain. Di sisi lain, pengalokasian waktu juga perlu diperhatikan oleh guru karena porsi setiap mata pelajaran berbeda-beda. Sehingga akan terjadi pada satu pertemuan pembelajaran tematik dimana ada mata pelajaran yang materinya sudah habis, namun masih memiliki jam pertemuan. Oleh karena itu, pelaksanaan pembelajaran tematik pada kurikulum 2013 dalam pelaksanaannya tidak dapat sepenuhnya sempurna, karena pembelajaran tematik menyesuaikan keluwesan dari mengoptimalkan minat dan kebutuhan siswa.

Penilaian siswa lebih banyak dilakukan pada proses pembelajaran maka guru setiap hari harus ada penilaian proses. Penilaian tersebut dijawujudkan dalam bentuk deskripsi yang dituliskan pada rapot hasil belajar siswa. Terdapat beberapa kendala yang dihadapi oleh guru dalam merumuskan deskripsi niali siswa pada rapor karena tidak terbiasa (Suswandari, 2017). Salahsatu kendalanya yaitu guru harus menuliskan kompetensi yang dikuasai siswa dan yang masih membutuhkan bimbingan guru. Oleh sebab itu, penulisan rapot secara deskripsi memang memberatkan tugas guru dan memerlukan waktu lama dalam pengerjaaanya, sehingga jadwal pembagian rapor sering mundur dari yang ditetapkan.

Guru menyadari bahwa penilaian begitu penting untuk mendapatkan umpan balik atas kinerjanya. Melalui penilaian guru dapat melihat dan

43 | Implementasi Pembelajaran Tematik di SDN Kemasan 1 Polokarto 


\section{Meidawati Suswandari}

menganalisis kekurangan selama proses pembelajaran tematik. Penyusunan penilaian pembelajaran tematik yang dibuat oleh guru SD N Kemasan 1 masih mengikuti dari buku guru ataupun buku siswa. Betapa pentingnya menyusun evaluasi pembelajaran di kelas tersebut, juga mengharuskan guru menyusun soal-soal evaluasi secara benar. Guru di SD N Kemasan 1 jarang menyusun soalsoal tes yang akan diujikan kepada siswa dengan langkah-langkah yang benar. Bahkan yang terjadi dari soal tersebut belum ada rubrik penilaian. Tidak adanya rubrik penskoran pada penilaian hasil belajar dapat berdampak pada ketidakpastian skala penilaian.

Penilaian siswa pada pembelajaran tematik lebih banyak dilakukan pada proses pembelajaran, setiap hari harus ada penilaian proses. Penilaian tersebut dipaparkan dalam bentuk deskripsi yang dituliskan pada rapot hasil belajar siswa. Hal inilah yang menjadikan optimalisasi dalam potensi siswa akan minat dan kebutuhan. Seperti yang dijelaskan oleh Gandasari (2019: 88) dan Sungkono (2006: 53) bahwa kelebihan pembelajaran tematik yaitu: a) Memberikan pengalaman dan kegiatan belajar anak relevan dengan tingkat perkembangannya, b) Kegiatan yang

\section{Kesimpulan}

Pelaksanaan

proses

pembelajaran tematik pada siswa kelas V SD N Kemasan 1 Polokarto terbagi dalam 6 karakteristik pembelajaran tematik, antara lain: 1) berpusat pada peserta didik. Artinya, pembelajaran sesuai dengan pendekatan belajar modern yang menempatkan siswa sebagai subjek belajar, sedangkan posisi guru sebagai fasilitator. 2) memberikan pengalaman langsung pada peserta didik (direct experiences) yang dihadapkan pada sesuatu yang nyata sebagai dasar untuk memahami hal-hal yang lebih abstrak. 3) pemisahan antara mata pelajaran tidak begitu nyata dan jelas yang diarahkan kepada pembahasan tema-tema yang paling dekat berkaitan dengan kehidupan siswa. 4) menyajikan suatu konsep dari berbagai mata pelajaran dalam suatu proses pembelajaran untuk memahami konsepkonsep tersebut secara utuh serta untuk membantu permasalahan siswa dalam kehidupan sehari-hari. 5) fleksibel atau luwes, artinya bahan ajar dalam satu 44 | Autentik: Jurnal Pengembangan Pendidikan Dasar, Vol.5, No.1, Februari 2021 
ISSN 2548-9119

mata pelajaran dapat dikaitkan dengan gur dapat benar-benar mata pelajaran yang lainnya, bahkan dapat dikaitkan dengan lingkungan tempat sekolah dan siswa berada. 6) hasil pembelajaran sesuai dengan minat dan kebutuhan siswa sebab siswa mengikuti pembelajaran tematik tanpa diberikan kesempatan untuk membedakan muatan pelajaran mengoptimalkan potensinya sesuai sehingga belajar dengan utuh dan dengan keinginannya. Pelaksanaan berdasarkan tema/sub tema yang pembelajaran tematik diharapkan bagi diberikan oleh guru.

\section{Daftar Pustaka}

Afandi, M., Evi, C., \& Oktarina, P. W. (2013). Model dan Metode Pembelajaran di Sekolah. Unisulla Press. https://doi.org/10.1007/s00423-006-0143-4

Akin, I. (2018). Of Student Self-Esteem And Resilience. Contemporary Issues in Education Research, 11(1), 15-22.

Arifin, S. (2016). Pengaruh Pembelajaran Tematik-Integratif Berbasis Sosiokultural Terhadap Hasil Belajar Peserta Didik Kelas lii Di Sekolah Dasar. Profesi Pendidikan Dasar, 3(1), 16. https://doi.org/10.23917/ppd.v3i1.2716

elliot ziwira. (2015). Creating a Conducive Learning Environment. Independent Development Fund, june, 1-11. http://www.herald.co.zw/creating-a-conducivelearning-environment/

Fayombo, G. A. (2015). Active learning strategies and student learning outcomes among some university students in Barbados. Journal of Educational and Social Research, 2(October), 79-90. https://doi.org/10.5901/jesr.2012.v2n9p79

Gandasari, M. . (2019). Pengembangan model pembelajaran tematik Pendidikan jasmani olahraga dan kesehatan untuk sekolah dasar. Jurnal Pendidikan Jasmani Indonesia, 15(1), 22-27.

Engaging students: creating classrooms that improve learning, (2017). http://www.grattan.edu.au/.

Irwan, M., \& Nasution, P. (2016). Strategi Pembelajaran Efektif Berbasis Mobile 45 | Implementasi Pembelajaran Tematik di SDN Kemasan 1 Polokarto 


\section{Meidawati Suswandari}

Learning pada Sekolah Dasar. Jurnal lqra, 10(01), 1-14. https://doi.org/10.1016/S0169-5347(97)01048-3

Misseyanni, A., Lytras, M. D., Papadopoulou, P., \& Marouli, C. (2018). Active Learning Strategies in Higher Education: Teaching for Leadership, Innovation, and Creativity. Emeral Publishing, April, 399.

Purwanti, S.D; Septiningrum, E.S, Hidayat, A.M; \& Hidayah, R. (2018). Implementation of thematic learning in the SD N 6 Panjer Kebumen. 3rd National Seminar on Educational Innovation (SNIP 2018), 3, 373-380.

Nugraha, S. A., Sudiatmi, T., \& Suswandari, M. (2020). Studi Pengaruh Daring Learning terhadap Hasil Belajar Matematika Kelas IV. Jurnal Inovasi Penelitian, 1(3), 265-276.

Suhendi, A., \& . P. (2018). Constructivist Learning Theory: The Contribution to Foreign Language Learning and Teaching. KnE Social Sciences, 3(4), 87. https://doi.org/10.18502/kss.v3i4.1921

Sungkono. (2006). Pembelajaran tematik dn implementasinya di Sekolah Dasar. Majalah IImiah Pembelajaran, 2(1), 51-58.

Suswandari, M. (2017). Keterampilan Guru Sekolah Dasar dalam Mengembangkan Bahan Ajar IPS. Edudikara: Jurnal Pendidikan dan Pembelajaran, 2(4), 354363.

Suswandari, M. (2018). Membangun budaya literasi bagi suplemen pendidikan di indonesia. Jurnal Dikdas Bantara, 1(1).

Suswandari, M. (2019). Cooperative Learning: Strategi Pengembangan Inovasi Pendidikan Di Indonesia. SCAFFOLDING: Jurnal Pendidikan Islam dan Multikulturalisme, 1(01), 16-24.

Wahyuni, H.T, Setyosari, P \& Kuswandi, D. (2016). Implementasi pembelajaran tematik kelas 1 SD. Edcomtech, 1(2), 129-136. 